\title{
Role of Zingiber Officinale Essential Oil- Chitosan Based Biopolymer Film For Bioactive Packaging
}

Sawsan A. Al-Hilifi ( $\nabla$ sawsan.hameed@uobsarah.edu.iq)

University of Basrah College of Agriculture https://orcid.org/0000-0002-4857-8157

\section{Rawdah M. Al-Ali}

University of Basrah College of Agriculture

\section{Research Article}

Keywords: Antimicrobial packaging, Ginger essential oil, chitosan films, biodegradable materials, food packaging, DSC, X-ray

Posted Date: September 29th, 2021

DOI: https://doi.org/10.21203/rs.3.rs-914536/v1

License: (a) (i) This work is licensed under a Creative Commons Attribution 4.0 International License. Read Full License 


\section{Abstract}

The recent interest in bio-packing at field of food become trending in the development of antimicrobial coatings. The focus of this study was to assess the potential application of zingiber officinale essential oil (GEO) in chitosan films (CHf). The data indicated that there were significant differences $(p<0.05)$ in the chemical composition of the samples.Forty-seven active compounds of the essential oil were identified from the rhizomes of ginger, which were identified byGC-MS. Fourier transforms infrared spectra (FT-IR) confirmed that an interaction between the hydroxyl groups of the phenolic compounds of the essential oil and the amide groups of polymer matrix. As shown the appearance of peaks at wavenumbers $1639 \mathrm{~cm}^{-1}$ and $1558 \mathrm{~cm}^{-1}$ Furthermore, X-ray diffraction results suggested a lower crystallintiyin CHf due to GEO effect. Differential Scanning Calorimetric (DSC) analysis revealed that CHf possessed high thermal stability, especially when different concentrations of GEO added. The bioactive $\mathrm{CHf}$ showed distinct activity against both positive and negative gram bacteria. They are Staphylococcus aurous, Bacillus subtillis, Streptococcus Sp. Escherichia coli, Salmonella Sp. Pseudomonas erugiosa. This results provides a comprehensive insight on the importance of films incorporated with EOs of interest in food packaging.

\section{Introduction}

Active packaging $(\mathrm{APg})$ is important in the food industry, as natural antimicrobial materials are combined to prevent or control outbreaks of infectious foodborne-associated, shelf-life lengthening of food products and improve the quality and safety standards of the packaged foods. The demand for bio-degradable and eco-friendly packaging is expected in the food packaging market around the world [1-3]. Biopolymers, such as proteins, carbohydrates and fats cover the requirements for obtaining bio-degradable films. These polymers can used individually or as mixture or mixed with other compounds. The films can cover the entire surface of the food and thus limit the effect of factors causing damage and improves the quality of food $[4,5]$. Bio-composite polysaccharide based material is receiving great attention because it is biodegradable and extends the shelf life of food [6]. APg means the change of the passive packaging system to the role of active defense, that conceder as catalyst for interaction between the environment, packaging and the product. APg ordinarily involves the intentional combination of discharging or absorption of certain compounds from or into the food packaging $[7,8]$. These active systems frequently contain active substances that can be released into the packaging's interior [9-11]. Moreover, biopolymer based films have proven to be an exceptional matrix for developing functional packaging materials through many additives, such as antioxidants, antimicrobial agents, flavors and colorings, etc., as they restrict the in inhibiting or spread of pathogenic microbes / food spoilage and contamination [12]. Therefore, active films can play an important role in packaging and thus preservation of fresh food ([13]. The essential oils (EOs) containing antimicrobial is a promising bio-active packaging technology, From a chemical point of view, EOs are secondary metabolites that are mixed with most of them terpenes, especially mono terpenes, containing their oxygenated derivatives, and other compounds such as hydrocarbon, ether, alcohol, aliphatic acid esters and phenolic, which are responsible for the antibacterial activities of EOs. $[14,15]$. Antimicrobial and antioxidant properties of essential oils are common, and they can be employed as a substitute for synthetic preservatives in the food industry [16]. Furthermore, EOs can 
be incorporated into biopolymer materials such as chitosan $(\mathrm{CH})$ to enhance the antimicrobial effect, i.e., Foodborne pathogens slow down, EOs have Generally Recognized as Safe (GRAS) status. [17, 18]. The essential oil of Ginger (Zingiber officinale) is well recognized for its antimicrobial ant oxidative and action [19]. These activities are usually attributed to some active compounds such as Zingiberene, Camphene, aCurcumene, and a-Phellandrene and The EOs contained mixture of chemical compounds including monoterpine hydrocarbons, oxygenated monoterpine, [20, 21]. $\mathrm{CH}$ is a homogenous polymer of $\mathrm{N}$-acetyl-DGlucose units linked to each by $\beta-(1 \rightarrow 4)$ bounds, we can get it form the exoskeleton of crustaceans, $\mathrm{CH}$ is a natural, sustainable and biocompatible material It has exciting and unique antimicrobial properties and is used in pharmaceutical, food packaging, and environmental conservation. [22-24]. Activities of $\mathrm{CH}$ is due to the reactive amino and hydroxyl functional groups, $\mathrm{CH}$ is frequently blended other polymers $\mathrm{Xu}$ etal.,2005). The resistance of bacteria and fungi to the in varied antimicrobial agents is main challenge within the treatment of the infections demand to the requirement for finding new sources of materials with anti-microbial properties, as the combination of essential oils and chitosan films coating may enhance the antibacterial properties [26]. The aim of this study is to highlight the effectiveness of antimicrobial chitosan films(CHf) as well to study some of their chemical properties. Hence, in this work we focus on develop active bio-packaging films, and assessment the influence of GEOs addition on thermal stability, morpho-structural(FTIR, XRD, and DSC) characteristics of the films produced. Moreover, the efficiency of GEOs-incorporated films in inhibiting the growth of some indicator food pathogenic bacteria against both gram-positive and gram-negative were determined.

\section{Materials And Methods \\ 2.1. Materials}

The shrimp shells used in the study were procured, sourced from the local market in Basrah city, Iraq. Shrimp shells was washed with distilled water and dried at $50^{\circ} \mathrm{C}$ for 12 hours, after that ground and stored at $4^{\circ} \mathrm{C}$ in polyethylene bags until the required test performed. Acetic acid, sodium hydroxide, hydrochloric acid, and glycerol were obtained from Sigma(Germany) respectively. Staphylococcus aureus PTCC 1337, Streptococcus Sp., Bacillus subtillis, Salmonella SP., Pseudomonas erugiosa, and Escherichia coli 015:H7 were obtained from the Department of Food Science, University of Basrah, Iraq. All strains were kept in nutrient broth(Sigma, Germany) at $-18^{\circ} \mathrm{C}$ until further use.

\subsection{Extraction of GEO}

The essential oil extraction process method befell within the laboratories of the department of Food Science/ college of Agriculture/University of Basrah. The ginger rhizomes (Zingiber officinale) were cleaned and then washed and peeled, and the EOs was extracted by steam distillation for $3 \mathrm{~h}$ using a Clevenger-type apparatus. EOs was dried over anhydrous sodium sulfate. Keep the GEO in tightly closed containers at $4 \circ \mathrm{C}$ prior to used .

\subsection{GC-MS analysis of GEO}


GEO were analyzed via GC/MS connected to QP-2010 system and GC-2010 (Shimadzu Co., Kyoto, Japan). A capillary column DB-5 (30 m $\times 0.25 \mathrm{~mm}$ id., film thickness $0.25 \mu \mathrm{m}$ ) was used to separate GEO. The components of EOs were identified by comparing their mass spectra to Wiley7n (Wiley, New York, NY, Technology, Gaithersburg, MD, USA). The peak area were used to calculate the relative percentages for the main components..

\subsection{Chitosan preparation}

The chitin was prepared to the method mentioned Trung et al. [27] with some modifications. The $\mathrm{CH}$ prepared by three treatments in which demineralization and deproteinization the first step: the shrimp shell $(7.5 \mathrm{~g})$ were treated with $1 \mathrm{~N} \mathrm{HCl}$ in the ratio of $1: 4(\mathrm{~W}, \mathrm{~V})$ at room temperature after 30 minutes, the shell washed with distilled water four times to remove the mineral and calcium chloride salts. The shrimp shell were then treated with $1 \mathrm{~N} \mathrm{NaOH} 1: 10(\mathrm{~W}: \mathrm{V})$ at $65^{\circ} \mathrm{C}$ at $1 \mathrm{~h}$ to remove the protein, Then the solution was filtered through Whatman No.1 to get rid of the insoluble parts, Then wash the filtrate with distilled water four times, then it was dried in oven at $50^{\circ} \mathrm{C}$ to get chitin. The preparation of $\mathrm{CH}$ is deacetylation of chitin [28] removing the acetyl groups from chitin was achieved by using $70 \% \mathrm{NaOH}$ at $85^{\circ} \mathrm{C}$ for 12 hours. The $\mathrm{CH}$ were washed with distilled water more than once to get rid of the base, poured into petri dishes and was dried at $50^{\circ} \mathrm{C}$, the $\mathrm{CH}$ was crushed into a fine powder and stored in light-permeable containers at $5 \pm$ $2^{\circ} \mathrm{C}$ before the next analysis.

\subsection{Determination of chemical composition}

Protein, moisture and ash contents of shrimp sells and chitosan were determination according to [29].

\subsection{Antimicrobial film preparation}

The biodegradable $\mathrm{CH}$ - based films in this study were prepared by $1 \mathrm{~g}$ of $\mathrm{CH}$ powder was dissolved in 100 $\mathrm{ml}(\mathrm{w} / \mathrm{v})$ in a $1 \%$ acetic acid and $1 \%$ glycerol and then stirred at $50^{\circ} \mathrm{C}$ for 30 minutes with a magnetic stirrer and was applied till the system entered in the homogenization, afterward, cool the solution to room temperature, and then $0,0.1,0.2$ and $0.3 \%(\mathrm{v} / \mathrm{w})$ of GEO were added to solution and homogenized for 30 min using a magnetic stirrer. The polymer solution put in a glass petri dishes to dry at $50^{\circ} \mathrm{C}$ overnight. The chitosan film without EOs was utilized as a control. The final thickness of $45 \pm 2 \mathrm{~mm}$ was determined in all samples. The dried films were peeled off and packed at $\left(\sim 25^{\circ} \mathrm{C}\right)$ with $55 \pm 2 \% \mathrm{RH}$ for $48 \mathrm{~h}$ for further characterization [30].

\subsection{Film characterization}

\subsubsection{Fourier-transform infrared spectroscopy (FT-IR)}

The effective groups were diagnosed according to the Bonilla et al.(2014)[31], as it included mixing films with potassium bromide $\mathrm{KBr}$ in a 100:1 ratio, than high pressure $2500 \mathrm{~kg} / \mathrm{cm}^{2}$ to obtain a small tablet of $1 \mathrm{~mm}$ in diameter and 1-2 $\mathrm{mm}$ thick putting the model pressed into FT-IR spectra ( Japanese company Jasco ). FTIR spectra were recorded in the region 4000 to $400 \mathrm{~cm}^{-1}$.

\subsubsection{Differential scanning calorimeter (DSC) analysis}


Thermodynamic properties of films was performed using DSC-200F3( Shimadzu, Japan) at a flow rate of $120 \mathrm{~mL} / \mathrm{min}$ in a nitrogen atmosphere. Approximately $10 \mathrm{mg}$ of films were placed in aluminum pans, and scanned at range of $30-400 \circ \mathrm{C}$ with a heating rate of $20^{\circ} \mathrm{C} / \mathrm{min}$. The curves of calorimetric analysis were recorded., the melting enthalpy $\left(\Delta H_{m}\right)$, melting temperature $\left(T_{m}\right)$, and thermal decomposition $\left(T_{d}\right)$ of the films were calculated from the resulting thermo grams.

\subsubsection{X-Ray diffraction analysis}

X-ray diffraction (XRD) patterns was analyzed with a X per T-pro pw 3050 in ambient condition using Cu$\mathrm{Ka}$ radiation and a nickel monochromator filtering wave at $40 \mathrm{kv}$ and $20 \mathrm{~mA}$. The bio-films were scanned from $2 \theta=5-50^{\circ}$ with a steep angle of $0.04 \mathrm{C} / \mathrm{min}$.[32].

\subsection{Antimicrobial activity of bio- films}

In vitro antimicrobial activity of GEO incorporated chitosan-based films was assessed by agar diffusion method to previous study of $[33,34]$. Six various spoilage bacteria and pathogenic consisting of Escherichia coli 015:H7, Staphylococcus aurous, Salmonella Sp., Bacillus subtilis, Pseudomomus aeruginosa, and Streptococcus Sp., were used as tested. All bacterial strains were cultured on nutrient broth slant for $24 \mathrm{~h}$ at $4^{\circ} \mathrm{C}$. The bio-active films sterilized with UV light were cut into circular shapes of $6 \mathrm{~mm}$ diameter, and the nutrient agar was poured into $15 \mathrm{ml}$ petri dishes for each plate and left to solidify. Then $0.1 \mathrm{ml}$ of inoculums which contains approximately $10^{4}-10^{6} \mathrm{CFU}$ were spread and the films cut were placed in the center, than the Petri dishes were incubated for 24 hours at $37^{\circ} \mathrm{C}$. The efficiency of the antibacterial agents was determined by the formation of an inhibitory zone around the disc samples. Films without GEO were used as a control and were treated according to the same methodology.

\subsection{Statistical analysis}

The results were analyzed statistically using a complete randomized design (CRD) with one factor, and the significant differences between the averages were compared using the LSD test at the 0.05 level and using the (SPSS version 13.0, 2012)

\section{Results And Discussion}

\subsection{Chemical Component of GEO}

GC-MS analysis of GEO showed different components (Table 1). Oxygenated monoterpenes, monoterpene hydrocarbons, diterpene hydrocarbons, sesquiterpene hydrocarbons, oxygenated sesquiterpenes, diterpene hydrocarbons, and fatty acid esters were all present in the EOs. The most essential components were Eucalyptol (19.36\%), (-) - Camphene (15.07\%), $\beta$-Bisabolene (11.52\%), Zingiberene (9.58\%), and Cineol (9.18\%) Fig. 1.Several compounds found in this GEO, such as(-) - Camphenein, alpha-curcumen, $a$ Zingiberene have known anti-bacterial properties. Moreover, the anti-bacterial properties may also be attributed to a.-Pinene, $\beta$-Selinenol, $\beta$-Sesquiphellandrene, and linalool. The major chemical constituents of GEO found in the current study were similar to those found in previous studies, we can notice that minor variations in concentrations due to changes in internal and external factors related to the growth 
environment, harvest season, and extraction process used. Wang et al. (2020) found that the $\beta$ Phellandrene, a-Curcumene, and $\alpha$-Zingiberene in the GEO were $2.56,12.04$, and $35.65 \%$, respectively. aZingiberene has also been identified by[35] to be one of the most abundant components of this oil.

Table 1. Chemical composition of ginger essential oil constituents using GC/GC-MS analysis 


\begin{tabular}{|c|c|c|}
\hline Components & $\mathrm{RT} / \mathrm{min}$ & $(\%)$ \\
\hline a-Pinene & 5.510 & 4.69 \\
\hline Camphene & 5.925 & 15.07 \\
\hline a-Phellandrene & 6.494 & 0.23 \\
\hline$\beta$-Pinene & 6.590 & 0.77 \\
\hline$\beta$-Myrcene & 7.018 & 2.03 \\
\hline Eucalyptol & 8.191 & 19.36 \\
\hline Norborneol & 12.181 & 4.47 \\
\hline a-Terpineol & 12.840 & 1.97 \\
\hline$\beta$-Bisabolene & 15.038 & 11.52 \\
\hline Cineol & 14.149 & 9.18 \\
\hline Lemomol & 14.533 & 0.63 \\
\hline Borneol & 15.232 & 0.33 \\
\hline a-Curcumene & 20.296 & 1.25 \\
\hline a-Zingiberene & 20.708 & 9.58 \\
\hline a-Farnesene & 20.930 & 1.81 \\
\hline Terpinolene & 20.971 & 1.21 \\
\hline $\mathrm{Y}$-Elemene & 21.203 & 0.71 \\
\hline$\beta$-Sequiphellandrene & 21.357 & 3.31 \\
\hline Zingiberone & 21.933 & 0.45 \\
\hline Nerolidol & 22.265 & 0.29 \\
\hline Spathulenol & 22.570 & 0.59 \\
\hline Globulol & 22.749 & 0.48 \\
\hline Elemol & 23.854 & 0.46 \\
\hline$\beta$-Selinenol & 24.494 & 1.42 \\
\hline Geraniol & 25.250 & 0.57 \\
\hline Geranialdehyde & 26.042 & 0.29 \\
\hline 6-Gingerol & 26.400 & 0.15 \\
\hline
\end{tabular}

\subsection{Chemical composition of chitosan}


The chemical compounds of fresh shrimp shell and extracted of chitosan are shown in Table 2. The chemical content of shrimp shell of moisture, protein and ash is $44.25 \%, 33.57 \%$ and $31.40 \%$ respectively. While values of, protein and ash decreased in the prepared chitosan as its values from $3.72 \%$ and $1.48 \%$ compared to raw shells. The shell sample contained a high ash and protein, so the ash percentage, directly related with the calcium carbonate in the exoskeleton [36]. These results indicate the efficiency of the demineralization, which is an essential step in prepared chitosan, as this treatment led to the removal of the largest possible amount of calcium carbonate and calcium phosphate, whose concentration in shell about $30-50 \%$ [37]. These result were similar to what [38] found, as composition of moisture, protein and ash of shrimp shell and chitosan particle size that were different as follow $45.65 \%, 32.45 \%, 32.77 \%$ respectively.

\section{Table2. Chemical composition of shrimp shell and chitosan prepared in different particle size}

\begin{tabular}{|llll|}
\hline Samples & \multicolumn{2}{l}{ Parameters (\%) } & \multicolumn{1}{c|}{ Ash } \\
\cline { 2 - 4 } & Moisture & $31.40 \pm 3.11$ & $33.57 \pm 2.87$ \\
Shrimp shell & $44.25 \pm 2.21$ & $1.48 \pm 1.92$ & $3.72 \pm 1.89$ \\
\hline Chitosan & $6.89 \pm 1.21$ & Protein \\
\hline
\end{tabular}

FTIR analysis of the films was used to describe the changes generated by the incorporation of GEO into bio-film interactions by separating the IR bands and vibrational shifts related to the incorporation of GEO into film. The spectrum of bio- films (Figure. 3) revealed distinct bands at around 3500 to $3000 \mathrm{~cm}^{-1}(\mathrm{NH}$ bond) and at $1630-1400 \mathrm{~cm}^{-1}$ ( $\mathrm{C}=\mathrm{O}$ bond) [39, 40], at $3398 \mathrm{~cm}^{-1}$ (axial stretch of $-\mathrm{OH}$ ); at $3271 \mathrm{~cm}^{-1}$ (an asymmetric extension of $-\mathrm{NH}$ group). The wide band in the range $3400-3000 \mathrm{~cm}^{-1}$ is attributable to $\mathrm{O}-\mathrm{H}$ and $\mathrm{N}-\mathrm{H}$ stretching vibration. Band at2939 to $2875 \mathrm{~cm}^{-1}$ (C-H bond to $-\mathrm{NHCOCH} 3$ of the methyl group); at $1639 \mathrm{~cm}^{-1}$ (amide I, C = O stretching); at $1558 \mathrm{~cm}^{-1}$ (amide II,N⿴囗十H bending ); at $1423-1382 \mathrm{~cm}^{-1}(\mathrm{CH} 2$ bending); at 1083 to $898 \mathrm{~cm}^{-1}$ (skeletal vibration including the stretching of the $\mathrm{C}-0$ group) and at 1155 to $1265 \mathrm{~cm}^{-1}$ (asymmetric stretching of the $\mathrm{C}-0-\mathrm{C}$ ). [41-44].General, the incorporation ginger oil did not in many differences in spectra compared to the control $\mathrm{CHf}$, perhaps this is due small amount incorporated, all peaks prevailed chitosan characteristic and all samples, slight changes in absorption peaks were recorded, which is due to the overlapping of chemical bonds and thus are considered evidence of an interaction between the molecules of different components. The FT-IR spectra of the GEO composition films show a new peak between 1745 to $1743 \mathrm{~cm}^{-1}$ that corresponds to the vibration of the $\mathrm{C}$ $=0$ bond stretch, it is an indication of interaction between the hydroxyl and amine groups of $\mathrm{CH}$ with the phenolic compounds in the essential oil [45].

\subsection{Thermal property of chitosan films}

The thermal analysis method is one of the physical method for evaluating a polymer endurance and stability in temperature range. In this study a DSC was used to estimate the tolerances of chitosan and 
chitosan/ ginger oil films as showed in Fig. 3 and Table 3.The result show that the $\mathrm{CHf}$ recorded the lowest melting point $\left(T_{m}\right)$ at $88.51^{\circ} \mathrm{C}$ and endothermic peak at $314.03^{\circ} \mathrm{C}$ which may be attributed to the moisture loss associated with the hydrophilic groups in chitosan and polymer decomposition, and which accounts for its crystallinity [46]. It is noticed that the highest value of the enthalpy of melting $(\Delta \mathrm{H})$ in the $\mathrm{CH}$ $10.3 \% \mathrm{GEO}$, as it was $526.02 \mathrm{~J} / \mathrm{g}$ and the lowest in the $\mathrm{GH}$ is $69.01 \mathrm{~J} / \mathrm{g}$. It is noticed from the figures that the greater the value of the change in the enthalpy in the model, the greater its ability to withstand high temperatures, In other words, the change in the model's entropy value increases with the increase in the degree of crystallization, so the more crystallized model is more resistant to higher temperatures. Increased crystallinity results in higher elasticity and in more breakable (lower TS) [47]. It is evident from the results that there is a direct relationship between the oil concentration in the films and crystallization, it may be caused by the movement of $\mathrm{CH}$ molecules to polymer segments, thus making them easier to arrange the polymer chain [48].

Table 3

Differential scanning calorimeter characteristics

\begin{tabular}{|lllll|}
\hline Characteristics & \multicolumn{3}{l}{ Films sample } & \\
\cline { 2 - 5 } & $\begin{array}{l}\text { Chitosan } \\
\text { (A) }\end{array}$ & $\begin{array}{l}\text { Chitosan/ginger01\% } \\
\text { (B) }\end{array}$ & $\begin{array}{l}\text { Chitosan/ginger0.2\% } \\
\text { (C) }\end{array}$ & $\begin{array}{l}\text { Chitosan/ginger0.3\% } \\
\text { (D) }\end{array}$ \\
\hline$\Delta \mathrm{H}(\mathrm{J} / \mathrm{g})$ & 69.01 & 104.16 & 181.55 & 526.02 \\
\hline Tm & 88.51 & 275.11 & 280.21 & 260.01 \\
\hline Ton & 279.55 & 186.71 & 180.42 & 188.24 \\
\hline Tp & 314.03 & 281.81 & 274.53 & 245.79 \\
\hline
\end{tabular}

\subsection{X-ray Diffraction}

X-ray diffraction analysis is used to ascertain the crystal structure of a substance by knowing the internal atomic space. XRD patterns of $\mathrm{CHf}$ with different amounts of GEO are shown in Fig. 4. Showed blunt peaks at $(2 \theta$ (ranging between $20-5$ this is in agreement with the assumption that $\mathrm{CH}$ is a molecularly crystallized polysaccharide that contains some crystals from the embedded in the amorphous region [49]. $\mathrm{CH}$ has the advantage of containing three forms: hydrated crystalline, anhydrous crystalline and no crystalline [50].The control $\mathrm{CHf}$ appeared in a crystalline state with a major diffraction peak at $5.7^{\circ}$ ( $2 \theta$ (,these results were consistent with [51] diffraction peak at $8.44^{\circ}$. According to what a previous study [52], the diffraction peak at $11.54^{\circ}$ is attributable to the anhydrous crystalline, at $18.34^{\circ}$ the diffraction peak is the aqueous crystal character [53]. Moreover, it was observed that diffraction peak at $22.8^{\circ}$ considered as typical fingerprint for $\mathrm{CHf}$ [54]. It was observed the diffraction peaks became flatter and less discernible when adding essential oil to the films, indicating a decrease in crystallinity with increasing concentration Usually, the crystallinity index values of films are lower when combined with EOs, it decrease the close packing in the polymer chains, this may be happen due to the stronger interaction between active 
compounds and biopolymers(i.e. H-bonds, Van der waals) this leads to improve the crystalline 3D-network $[55,56]$.

\subsection{Antimicrobial activity}

The antimicrobial activity of chitosan bio-active films containing GOE at were exhibited in the Table 4. Control compound $\mathrm{CHf}$ The film (without essential oil) had the lowest antimicrobial activity compared to other films against the studied microorganisms. Mechanism for anti-microbial activity of $\mathrm{CH}$ is based on its positive charges $\left(\mathrm{NH}_{3}{ }^{+}\right)$, which interfere with the electro negative charged on the cell membrane permeability. Leakage of proteinaceous, ionic, and other intracellular materials causes cell death [57-60]. Since $\mathrm{CH}$ cannot disperse through agar media and only species that come into contact with the active areas of $\mathrm{CH}$ are affected [61-63]. In this study, The growth of the six pathogens was inhibited by all active bio-films in a way depends on concentration EOs. Zone of inhibition increased significantly $(p<0.05)$ as the concentration of GEO in the films increased. CHf with the highest concentration of GEO $(0.3 \% \mathrm{w} / \mathrm{v})$ effectively affected the growth of tested bacteria, resulting in halos between 9.02 to $18.35 \mathrm{~mm}$. The antibacterial activity of EOs is thought to be due to their high phenolic content [64,65]. In general, EOs have a higher susceptibility to Cram-positive bacteria than to Cram-negative bacteria [66]. GEO was found to have antibacterial activity against S. by [67], while Singh et al. (2008)[68] found strong antimicrobial activity against E. coli, S. aureus, and Yersinia enterocolitica. This could be the results of synergism generated by the mixture of $\mathrm{CH}$ and EOs maybe due to the presence of activity compound and terpenoid that could have antibacterial effect such as Zingerone, shogaol, nerolido and anther Phenolic compounds [68, 69], when analyzing red ginger oil with the GC MS technique by[70] they found that it contains the following compounds Curcumene (15.6\%); zingiberene (10.3\%); $\beta$-Sesquiphellandrene (8.74\%); Cineole (7.52\%); $\alpha$ Pinene (3.12\%); and borneol (0.46\%), these compounds have anti-bacterial properties. The effect of EOs on microorganisms is due to several mechanisms, including their effect on the permeability of the cell membrane, disruption of enzyme systems, which affects the genetic material of the bacteria, as the aromatic and phenolic compounds of the oils affect the cytoplasmic membrane and change its function, and to the inhibition of intracellular metabolic pathways [71-73].This is confirmed by [74], as thy showed that adding essential oils such as GEO improves the anti-bacterial properties of $\mathrm{CHf}$. 
Table 4

Antimicrobial activity of edible films incorporated GEO.

\section{Bacterial strains}

\begin{tabular}{|c|c|c|c|c|c|c|}
\hline $\begin{array}{l}\text { Films } \\
\text { with oil } \\
\text { conc. } \%\end{array}$ & $\begin{array}{l}\text { Escherichia } \\
\text { coli 015:H7 }\end{array}$ & $\begin{array}{l}\text { Staphylococcus } \\
\text { aurous }\end{array}$ & $\begin{array}{l}\text { Salmonella } \\
\text { Sp. }\end{array}$ & $\begin{array}{l}\text { Bacillus } \\
\text { subtilis }\end{array}$ & $\begin{array}{l}\text { domonas } \\
\text { iosa }\end{array}$ & $\begin{array}{l}\text { Streptococcus } \\
\text { Sp. }\end{array}$ \\
\hline \multicolumn{7}{|c|}{ inhibition zone $(\mathrm{mm})$} \\
\hline Control & $8.81 \pm 0.00$ & $11.44 \pm 0.11$ & $9.77 \pm 0.36$ & $12.80 \pm 0.006$ & $\begin{array}{l}10.72 \pm \\
0.008\end{array}$ & $11.38 \pm 0.010$ \\
\hline $0.1 \%$ & $9.02 \pm 0.01$ & $12.62 \pm 0.00$ & $\begin{array}{l}11.84 \pm \\
0.017\end{array}$ & $14.66 \pm 0.005$ & $\begin{array}{l}13.27 \pm \\
0.008\end{array}$ & $15.25 \pm 0.00$ \\
\hline $0.2 \%$ & $\begin{array}{l}11.38 \pm \\
0.01\end{array}$ & $14.91 \pm 0.005$ & $\begin{array}{l}12.57 \pm \\
0.008\end{array}$ & $15.26 \pm 0.021$ & $\begin{array}{l}13.36 \pm \\
0.015\end{array}$ & $15.44 \pm 0.015$ \\
\hline $0.3 \%$ & $\begin{array}{l}13.11 \pm \\
0.02\end{array}$ & $17.35 \pm 0.01$ & $\begin{array}{l}14.95 \pm \\
0.017\end{array}$ & $17.52 \pm 0.008$ & $\begin{array}{l}14.90 \pm \\
0.012\end{array}$ & $18.35 \pm 0.012$ \\
\hline
\end{tabular}

\section{Declarations}

\section{CRediT authorship contribution statement}

Sawsan A. Al-Hilifi: Conceptualization, Methodology, Validation, Investigation, Writing - original draft, Review, Writing, and Editing. Rawdah M. Al-Ali: , Formal analysis, Conceptualization, Investigation, Software, Data curation.

\section{Declaration of competing interest}

This work did not receive any specific grant from funding agencies in the public, commercial, or not-forprofit sectors. The authors declare that they have no known competing financial interests or personal relationships that could have appeared to influence the work reported in this paper.

\section{Ethical statement}

This article does not contain any studies with human participants performed by any of the authors.

\section{References}

1. Al-Ali RM, Al-Hilifi SA, Rashed MMA (2021) Fabrication, characterization, and anti-free radical performance of edible packaging-chitosan film synthesized from shrimp shell incorporated with ginger essential oil. Journal of Food Measurement Characterization 8:9-16. https://doi.org/10.1007/s11694-021-00875-0

2. Anter HM, Abu Hashim II, Wadin W, Meshali MM (2019) Novel chitosan oligosaccharide- based nanoparticles for gastric mucosal administration of the phytochemical "apocynin". Int J Nanomed 


\section{$14: 4911-4929$}

3. AOAC (2007). Official Method of Analysis of the Association of Official Analytical Chemistry (A.O.A.C) International, 18th edn. Gaithersburg, Maryland

4. Avelelas F, Horta A, Pinto LFV, Marques SC, Nunes PM, Pedrosa R, Leandro SM (2019) Antifungal and antioxidant properties of chitosan polymers obtained from nontraditional Polybius henslowii source. Mar Durgs 17(239):2-15

5. Ávila A, Bierbrauer K, Pucci G, López-González M, Strumia M (2012) ). Study of optimization of the synthesis and properties of bio composite films based on grafted chitosan. J Food Eng 109:752-761

6. Babapour $\mathrm{H}$, Jalali $\mathrm{H}$, Nafchi AM (2021) The synergistic effects of zinc oxide nanoparticles and fennel essential oil on physicochemical, mechanical, and antibacterial properties of potato starch films. Food Science\& Nutrition 9(7):3893-3905

7. Binsi K, Ravishankar CN, Gopal TK (2013) Development and characterization of an edible composite film based on Chitosan and virgin coconut oil with improved moisture sorption properties. Journal of Food Science., 78, Nr. 4

8. Bourbon Al, Pinheiro AC, Cerqueira MA, Rocha CMR, Avides MC, Quintas MAC et al (2011) Physicochemical characterization of chitosan-based edible films incorporating bioactive compounds of different molecular weight. J Food Eng 106(2):111-118. https://doi.org/10.1016/j.jfoodeng.2011.03.024

9. Boyacı D, lorio G, Sozbilen GS, Alkan D, Trabattoni S, Pucillo F, Farris S, Yemenicioğlu H (2019) Development of flexible antimicrobial zein coatings with essential oils for the inhibition of critical pathogens on the surface of whole fruits: Test of coatings on inoculated melons. Food Packaging Shelf Life 20:100316

10. Braber NLV, Di Giorgio L, Aminahuel CA, Vergara LID, Costa AOM, Montenegro MA et al (2020) Antifungal whey protein films activated with low quantities of water soluble chitosan. Food Hydrocolloids, 106156

11. Burt S (2004) Essential oils: Their antibacterial properties and potential applications in foods a review. Int J Food Microbiol 94(3):223-253. https://doi.org/10.1016/j.ijfoodmicro.2004.03.022

12. Cao TL, Yang SY, Song KB (2018) ). Development of burdock root inulin/chitosan blend films containing oregano and thyme essential oils. Int J Mol Sci 19(1):131

13. Chatterjee S, Adhya M, Guha AK, Chatterjee BP (2005) Chitosan from Mucor rouxii: production and physic-chemical characterization. Process Biochem 40:395-400

14. Chawla R, Kaur H(2021). Antimicrobial edible films in food packaging: current scenario an recent nan technological advancements- a review. Carbohydrate Polymer Technologies Applications.2021.volume2,https://doi.org/10.1016/j.carpta

15. Coma V, Martial-Gros A, Garreau S, Copinet A, Salin F, Deschamps A (2002) Edible antimicrobial films based on chitosan matrix. J Food Sci 67:1162-1169

16. Dutta PK, Duta JD, Tripathi VS (2004) Chitin and chitosan: Chemistry, properties and applications. Journal of Scientific industrial Research 63(1):20-31 
17. Ekramian S, Abbaspour H, Roudi H, Amjad L, Nafchi AM (2021) An experimental study on characteristics of sago starch film treated with methanol extract from Artemisia sieberi Besser.(2021). Journal of Food Measurement Characterization 15:3298-3306. https://doi.org/10.1007/s11694-02100895-w

18. Haghighi H, Biard S, Bigi F, De Leo R, Bedin E, Pfeifer F, Siesler HW, Licciardello F, Pulvirenti A (2019) Comprehensive characterization of chitosan-gelatin blend films enriched with different essential oils. Food Hydrocolloids 95:33-42

19. Holley RA, Patel D (2005) Improvement in shelf-life and safety of perishable foods by plant essential oils and smoke antimicrobials. Food Microbiol 22:273-292

20. Hosseini SF, Ghaderi J, G'omez-Guill'en MC (2021) Trans- Cinnamaldehyde-doped quadripartite bio polymeric films: Rheological behavior of film-forming solutions and bio functional performance of films. Food Hydrocolloids 112:106339

21. Huang T, Qian Y, Wei J, Zhou C (2019) Polymeric antimicrobial food packaging and its applications. Polymers 11:560

22. Irawan A, Barleany DR, Yulvianti JM, Jayanudin J (2017) Antimicrobial Activity of Chitosan Based Edible Film Enriched with Red Ginger Essential Oil as An Active Packaging for Food. RJPBCS 8(3):1525-1530

23. Irawan A, Barleany DR, Yulvianti M, Maulana RC, Fitriani LY (2019) Chitosan active films containing red ginger extract for shelf-life extension and quality retention of Milkfish (Chanos chanos). AIP Conference Proceedings 2085, 02003

24. Islam S, Bhuiyan MA, Islam MN (2017) Chitin and chitosan: Structure, properties and applications in biomedical engineering. J Polym Environ 25(3):854-866

25. Jahdkaran E, Hosseini SE, Nafchi EM (2021) The effects of methylcellulose coating containing carvacrol or menthol on the physicochemical, mechanical, and antimicrobial activity of polyethylene films. Food Nutration 9.5:2768-27787

26. Kanatt SR, Rao MS, Chawla SP, Sharma A (2012) Active chitosan-polyvinyl alcohol films with natural extracts. Food Hydrocolloids 29(2):290-297. https://doi.org/10.1016/j.foodhyd.2012.03.005

27. Knorr D (1984) Use of chitin us polymers in food-A challenge food research and development. Food Technol 38(1):85-97

28. Kumar N, Petkoska AT, AL-Hilifi SA, Fawole OA (2021) Effect of Chitosan-Pullulan Composite Edible Coating Functionalized with Pomegranate Peel Extract on the Shelf Life of Mango (Mangifera indica). Coatings 11(7):764

29. Lago MA, Sendon R, Rodriguez-Bernaldo de Quiros, A, Sanches-Silva A, Costa HS, Sanchez-Machado DI, Valdez S, Angulo H, Aurrekoetxea I, Torrieri GP (2014) E., et al. Preparation and Characterization of Antimicrobial Films Based on Chitosan for Active Food Packaging Applications. Food Bioprocess Tech 7:2932-2941

30. Liang J, Wang R, Chen R (2019) The impact of cross-linking mode on the physical and antimicrobial properties of a chitosan/bacterial cellulose composite. Polymers 11:491-506. 
https://doi.org/10.3390/polym11030491

31. Lijun S, Jiaojiao S, Chen L, Niu P, Yang X, Guo Y (2017) Preparation and characterization of chitosan film incorporated with thinned young apple polyphenols as an active packaging material. Carbohyd Polym 163:81-91. https://doi.org/10.1016/j.carbpol.2017.01.016

32. López EIC, Balcázar MFH, Mendoza JMR, Ortiz ADR, Melo MTO, Parrales RS, Delgado TH (2017) Antimicrobial activity of essential oil of Zingiber officinale Roscoe (Zingiberaceae). Am J Plant Sci 8:1511-1524

33. Lukic I, Vulic J, Ivanovic J (2020) Antioxidant activity of PLA/PCL films loaded with thymol and/or carvacrol using scCO2 for active food packaging. Food Packaging Shelf Life, 26, 100578. https:// doi.org/10.1016/j.fpsl.2020.100578

34. Majid J (2009) ). Biodegradable whey protein edible films anew biomaterials for food and drug packaging. Iranian Journal of Pharmaceutical Sciences 5(3):129-134

35. Matan N, Rimkeeree H, Mawson AJ, Chompreeda P, Haruthaithanasan V, Parker M (2006) Antimicrobial activity of cinnamon and clove oils under modified atmosphere conditions. Int. J. Food Microbiol. 2006, 107, 180-185. 10.1016/j.ijfoodmicro.2005.07.007

36. Mathew S, Brahmakumar M, Abraham T (2006) Microstructural imaging and characterization of the mechanical, chemical, thermal, and swelling properties of starch-chitosan blend films. Biopolymers 82:176-187. https://doi.org/10.1002/bip.20480

37. Moslehi Z, Mohammadi Nafchi A, Moslehi M, Jafarzadeh S (2021) Aflatoxin, microbial contamination, sensory attributes and morphology analysis of pistachio nut coated with methylcellulose. Food Science Nutrition. https://doi.org/10.1002/fsn3.2212

38. Nady N, Kandil SH (2019) Novel blend for producing porous chitosan-based films suitable for biomedical applications. Membranes 8(2):1-18. https://doi.org/10.3390/membranes8010002

39. Noshirvani N, Ghanbarzadeh B, Gardrat PS, Lopes CMP, Yoshida, Silva CF (2017) Cinnamon and ginger essential oil improve antifungal, physical and mechanical properties of chitosan-carboxymethyl cellulose films. Food Hydrocolloids 70:2-20. doi:10.1016/j.foodhyd.2017.03.015

40. Pintatum A, Laphookhieo S, Logie E, Berghe WV, Maneerat W (2020) Chemical composition of essential oils from different parts of Zingiber kerrii Craib and their antibacterial, antioxidant, and Tyrosinase inhibitory activities. Biomolecules 10:228. doi:10.3390/biom10020228

41. Qin YY, Zhang ZH, Li L, Yuan ML, Fan J, Zhao TR (2015) Physio-mechanical properties of an active chitosan film incorporated with montmorillonite and natural antioxidants extracted from pomegranate rind. J Food Sci Technol 52:1471-1479. doi:10.1007/s13197-013-1137-1

42. Raphaël KJ, Meimandipour A (2017) Antimicrobial activity of chitosan film forming solution enriched with essential oils; an vitro assay. Iranian J Biotech 15(2):111-119

43. Remya ,S 1, Mohan CO, Bindu J, Sivaraman1 GK, Venkateshwarlu G, Ravishankar CN (2016). Effect of chitosan based active packaging film on the keeping quality of chilled stored barracuda fish. J Food Sci Technol 53(1):685-693 
44. Ribeiro-Santos R, Andrade M, de Melo NR, Sanches-Silva A (2017) Use of essential oils in active food packaging: Recent advances and future trends. Trends Food Sci Technol 61:132-140. https://doi.org/10.1016/j.tifs.2016.11.021

45. Romainor ANB, Chin SF, Pang SC, Bilung LM (2014) Preparation and characterization of chitosan nanoparticles-doped cellulose films with antimicrobial property. Journal of Nanomaterials. http://dx.doi.org/10.1155/2014/710459

46. Salvia-Trujillo L, Rojas-Graü A, Soliva-Fortuny R, Martín-Belloso O (2015) Physicochemical characterization and antimicrobial activity of food-grade emulsions and nanoemulsions incorporating essential oils. Food Hydrocolloids, 43, 547-556. https://doi.org/10.1016/j.foodhyd.2014.07.012

47. Samar MM, EL-Kalyoubi MH, Khalf MM, Abd EL-Razik MM (2013) Physicochemical, functional, antioxidant and antibacterial wastes by microwave technique. Annals Agricultural Science 58,(1):3341. https://doi.org/10.1016/j.aoas.2013.01.006

48. Sasidharan I, Venugopal VV, Menon AN (2012) Essential oil composition of two unique ginger (Zingiber officinale Roscoe) cultivars from Sikkim. Nat Prod Res 19:1759-1764. doi:10.1080/14786419.2011.571215

49. Seydim AC, Sarikus G (2006) Antimicrobial activity of whey protein based edible films incorporated with oregano, rosemary and garlic essential oil. Food Res 26:639-644. https://doi.org/10.1016/j.foodres.2006.01.013

50. Shahzadi K, Wu L, Ge X, Zhao F, Li H, Pang S, Jiang Y, Guan J, Mu X (2016) Preparation and characterization of bio-based hybrid film containing chitosan and silver nanowires. Carbohyd Polym 137:225-232. https://doi.org/10.1016/j.carbpol.2015.11.012

51. Silva-Weiss A, Bifani V, Ihl M, Sobral PJA, Gómez-Guillén MC (2013) Structural properties of films and rheology of film-forming solutions based on chitosan and chitosan-starch blend enriched with murta leaf extract. Food Hydrocolloids 31:458-466. https://doi.org/10.1016/j.foodhyd.2012.11.028

52. Singh G, Kapoor IPS, Singh P, Heluani CS, Lampasona MP, Catalan CAN (2008) Chemistry, antioxidant and antimicrobial investigations on essential oil and oleoresins of Zingiber officinale. Food Chem Toxicol 46:3295-3302. https://doi.org/10.1016/j.fct.2008.07.017

53. Siripatrawan U, Harte BR (2010) Physical properties and antioxidant activity of an active film from chitosan incorporated with green tea extract. Food Hydrocoll 24:770-775

54. Souza VGL, Pires JRA, Rodrigues C, Rodrigues PF, Lopes A, Silva RG, Caldeira J, Duarte MP, Fernandes FP, Coelhoso IM, Fernando AL (2019) Physical and Morphological Characterization of Chitosan/Montmorillonite Films Incorporated with Ginger Essential Oil. Coating 9(700):2-20. https://doi.org/10.3390/coatings9110700

55. Sriacusa V, Rocculi P, Romani S, Rosa MD (2008). Biodegradable polymer for food packaging: A review. Trends in Food Science \&Technology 19(12):634-643.

https://doi.org/10.1016/j.tifs.2008.07.003

56. Srinivasa PC, Ramesh MN, Kumar KR, Tharanathan RN (2004) Properties of chitosan films prepared under different drying conditions. J Food Eng 63:79-85. https://doi.org/10.1016/S0260- 
8774(03)00285-1

57. Stoicai P, Chifriuc MC, Rapal M, Bleotiu C, Lungu L, Vladi G, Grigores R, Bertesteanu S, Stavropouloue E, Lazar V (2015) Fabrication, characterization and bioevaluation of novel antimicrobial composites based on polycaprolactone, chitosan and essential oils. Romanian Biotechnological Letters 20(3):10521-10535

58. Sung S-Y, Sin LT, Tee T-T, Bee S-T, Rahmat AR, Rahman WAWA, Tan A-C, Vikhraman M (2013) Antimicrobial agents for food packaging applications. A review. Trends Food Sci Technol 33:110-123. https://doi.org/10.1016/j.tifs.2013.08.001

59. Tajkarimi MM, Ibrahim SA, Cliver DO (2010) Antimicrobial herb and spice compounds in food. A review. Food Control 21:1199-1218

60. Teerarak M, Laosinwattana C (2019) Essential oil from ginger as a novel agent in delaying senescence of cut fronds of the fern (Davallia solida (G. Forst.) Sw.). Postharvest Biol Tec 156:110927. https://doi.org/10.1016/j.postharvbio.2019.06.001

61. Trajano VN, Lima O, Leite E, Travassos R(2009). Propriedade antibacteriana de óleos essenciais de especiarias sobre bactérias contaminantes de alimentos. 2009, 29, 542-545

62. Trung TS, Tram LH, Tan NV, Hoa NV,. Minh NC, Loc PT, Stevens WF (2020) Improved method for production of chitin and chitosan from shrimp shells. Carbohydrate Res 489:107913. https://doi.org/10.1016/j.carres.2020.107913

63. Uranga J, Etxabide A, Guerrero P, Caba K (2018) Development of active fish gelatin films with anthocyanins by compression molding. Food Hydrocolloids 84:313-320. https://doi.org/10.1016/j.foodhyd.2018.06.018

64. Verlee A, Mincke S, Stevens CV (2017) Recent developments in antibacterial and antifungal chitosan and its derivatives. Carbohydr Polym 164:268-283

65. Wang X, Shen Y, Thakur K, Han J, Zhang JG, Hu F, Wei ZJ(2020). Antibacterial activity and mechanism of ginger essential oil against Escherichia coli and Staphylococcus aureus., Molecules, 25, 3955; 217,doi:10.3390/molecules25173955

66. Woranuch S, Yoksan R Eugenol-loaded chitosan nanoparticles: II.(2013).Application in bio-based plastics for active packaging. Carbohydr. Polym., 96, 586-592.

https://doi.org/10.1016/j.carbpol.2012.09.099

67. Wu J, Shangying G, HuiL, Shuang W, Shanfei C, Jianhua W, Jianhua L, Qiqing Z (2014) Properties and antimicrobial activity of silver carp (Hypophthalmichthys molitrix) skin gelatin-chitosan films incorporated with oregano essential oil for fish preservation. Food Packaging Shelf Life 2:7-16. https://doi.org/10.1016/j.fpsl.2014.04.004

68. Xu YX, Kim KH, Hanna MA, Nag D (2005) Chitosan-starch composite film: Preparation and characterization. Ind Crops Prod 21:185-192. https://doi.org/10.1016/j.indcrop.2004.03.002

69. Yam KL, Lee DS (eds) (2012) Emerging food packaging technologies, an overview, Woodhead Publishing Series in Food Science, Technology and Nutrition. pp. 1-9. https://doi.org/10.1533/9780857095664.1 
70. Yildirim S, Röcker B, Pettersen MK, Nilsen-Nygaard J, Ayhan Z, Rutkaite R et al (2018) Active packaging applications for food Compr. Rev Food Sci Food Saf 17:165-199. 10.1111/15414337.12322

71. Ziani K, Oses J, Coma V, Mate JI (2008) Effect of the presence of glycerol and tween 20 on the chemical and physical properties of films based on chitosan with different degree of deascetylation. LWt-Food Science Technology 41:2159-2165

72. Zinn S, Betz T, Medcraft C, Schnell M (2015) Structure determination of trans-cinnamaldehyde by broadband microwave spectroscopy. Phys Chem Chem Phys 17:10680-16085. doi:10.1039/C5CP02582F

73. Bonilla J, Fortunati E, Atarés L, Chiralt A, Kenny JM (2014) Physical, structural and antimicrobial properties of poly vinyl alcohol-chitosan biodegradable films. Food Hydrocolloids, 35(Supplement C), 463-470. https://doi.org/10.1016/j.foodhyd.2013. 07.002

74. Bergo P, Sobral PJA (2007) Effects of plasticizer on physical properties of pigskin gelatin films. Food Hydrocolloids, 21(8), 1285-1289. https://doi.org/10.1016/j. foodhyd.2006.09.014

\section{Conclusion}

In this study, the incorporation of GEO into chitosan was successfully prepared bioactive polymers. Characterization of bio composite active films was determined by using Several methods of analysis in order to assess the effect of incorporating GEO in the polymer. Bioactive films based on CH/GEO showing both melting temperature $\left(T_{\mathrm{m}}\right)$ and endothermic peak $\left(T_{\mathrm{p}}\right)$ had a semi-crystalline structure. The contact angle decreased with EOs addition, so, CHf / GEO coating films have a more hydrophobic surface than pristine $\mathrm{CHf}$. A semi-crystalline polymer crystallographic morphology is normally noticeably changed by EOs effect. The molecular interactions that occurred after the addition of GEO were characterized using FTIR analysis. The films were effective against foodborne pathogens in general. Food packaging is critical for preventing bacterial contamination. Biodegradable food packaging, on the other hand, is more promising in the long term because it is green, recycled, and environmentally friendly. In light of the results, it can be concluded that the addition GEO to antimicrobial films can provide a promising future for biodegradable food packaging applications.

\section{Figures}




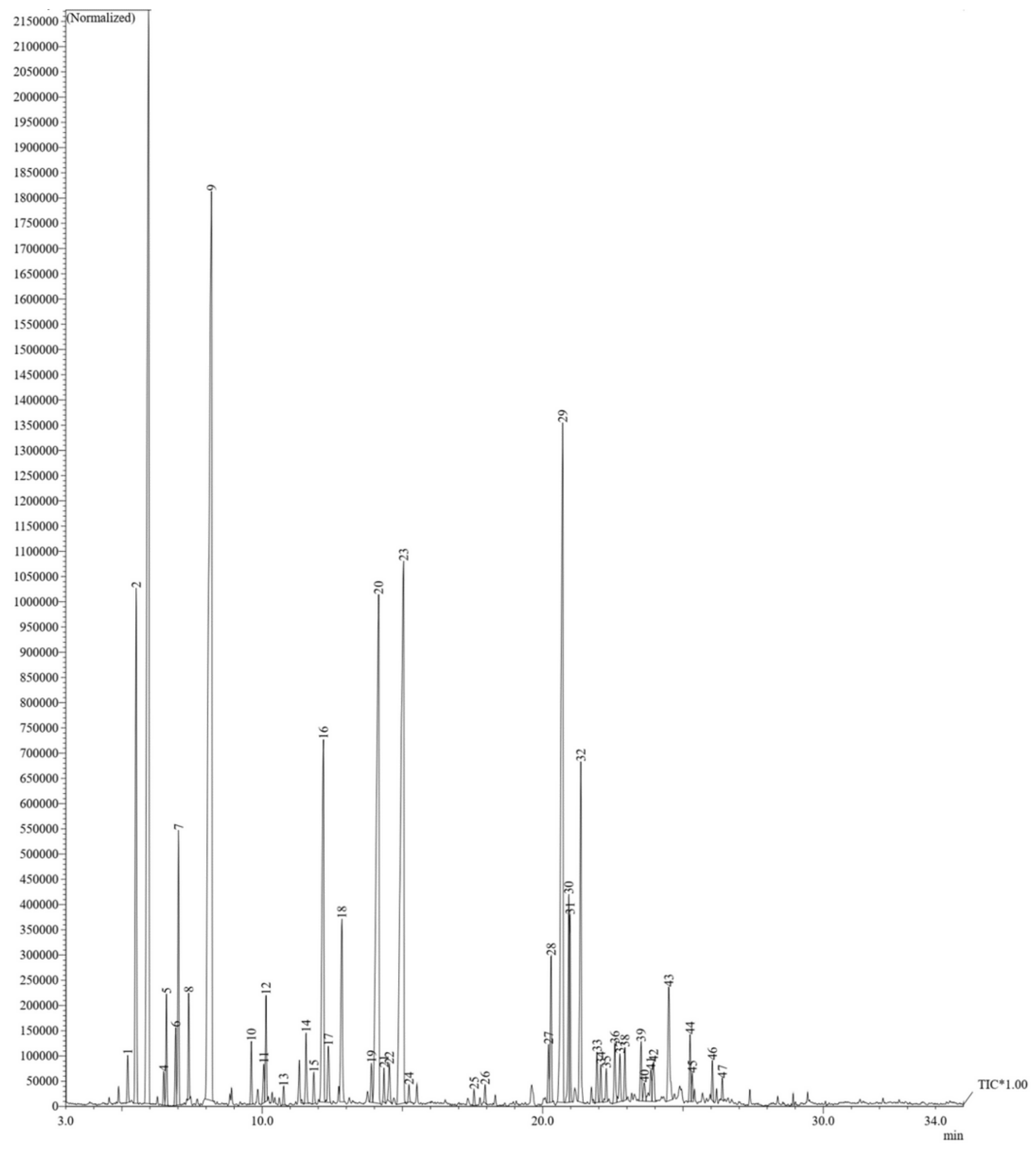

Figure 1

Typical Chromatogram of Total ion current plot of essential oil isolated from the rhizomes of ginger from GC-MS analysis. 


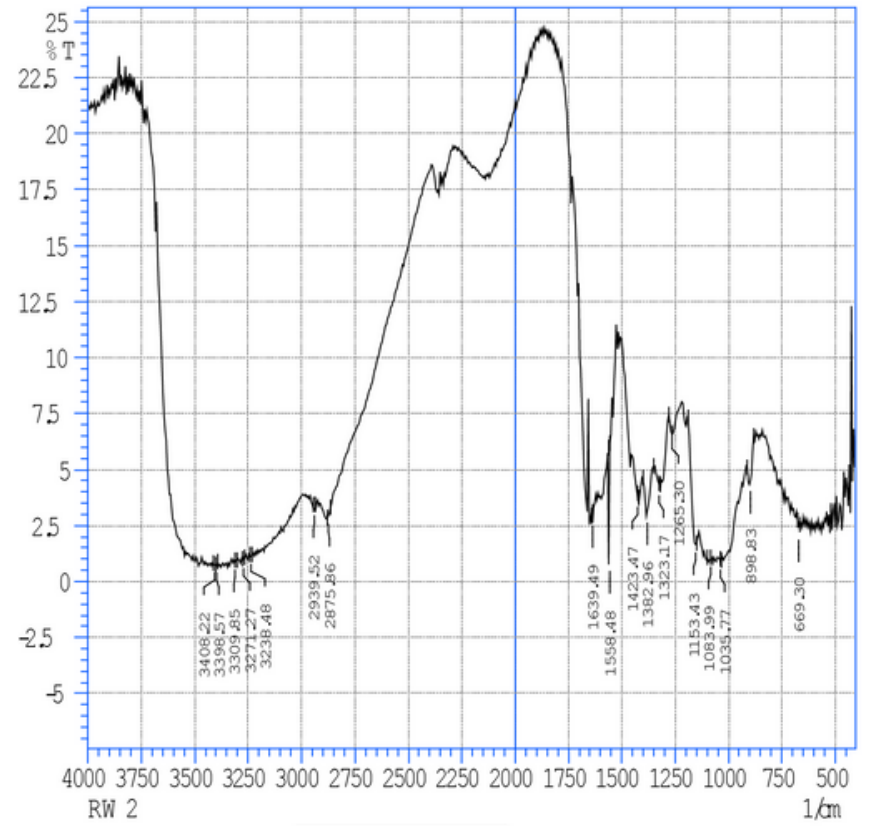

a. FTIR

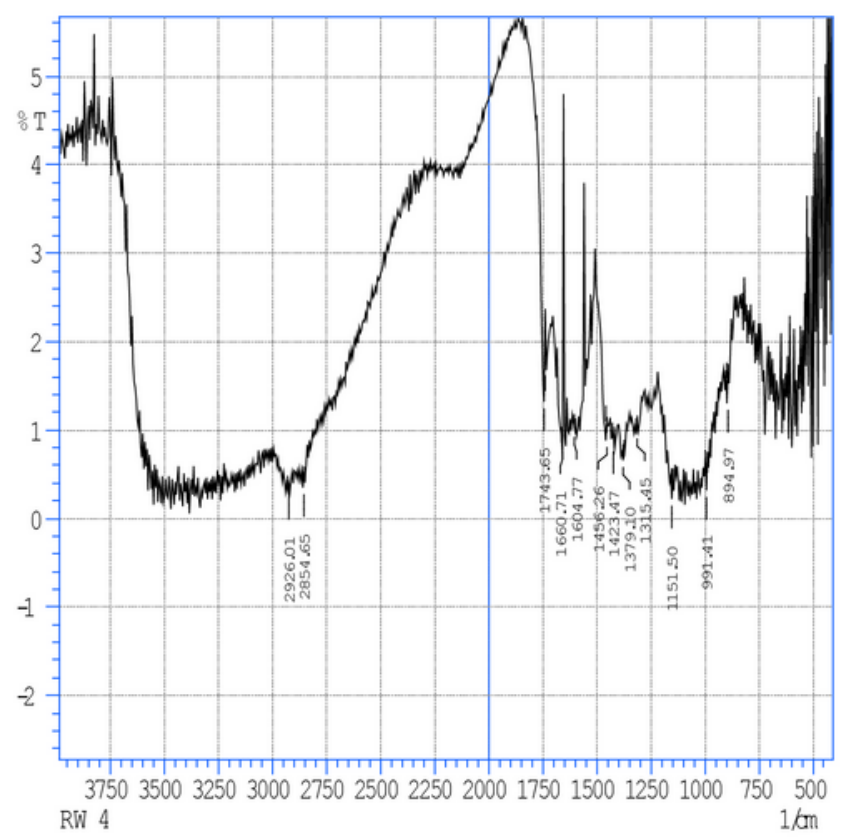

c. FTIR

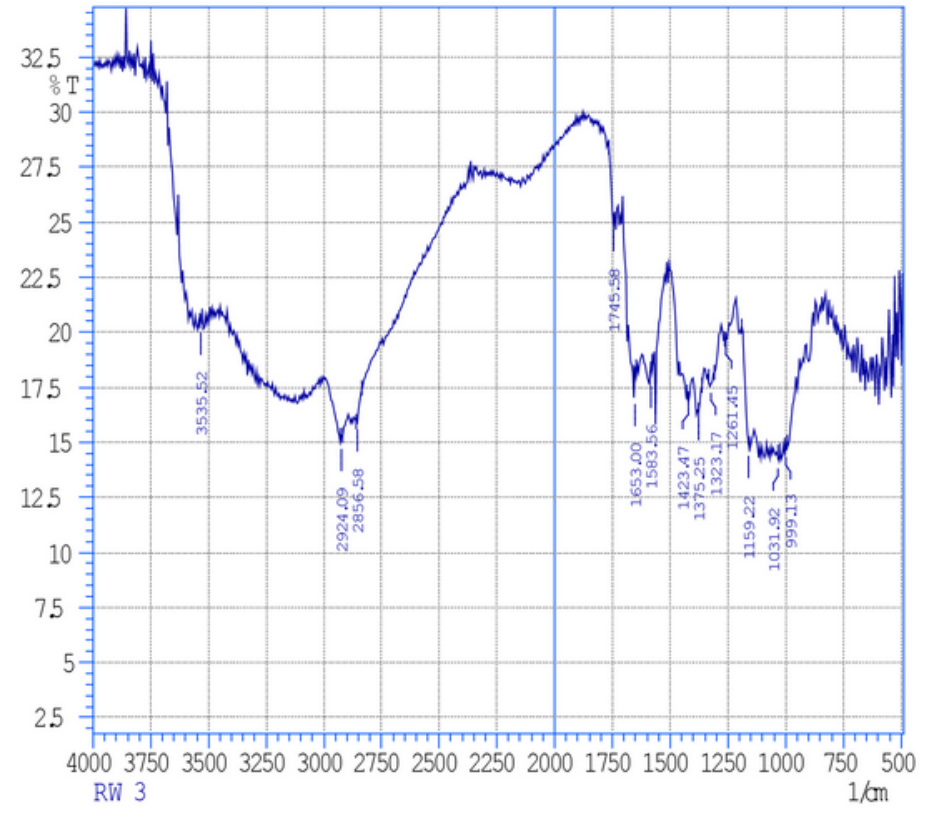

b. FTIR

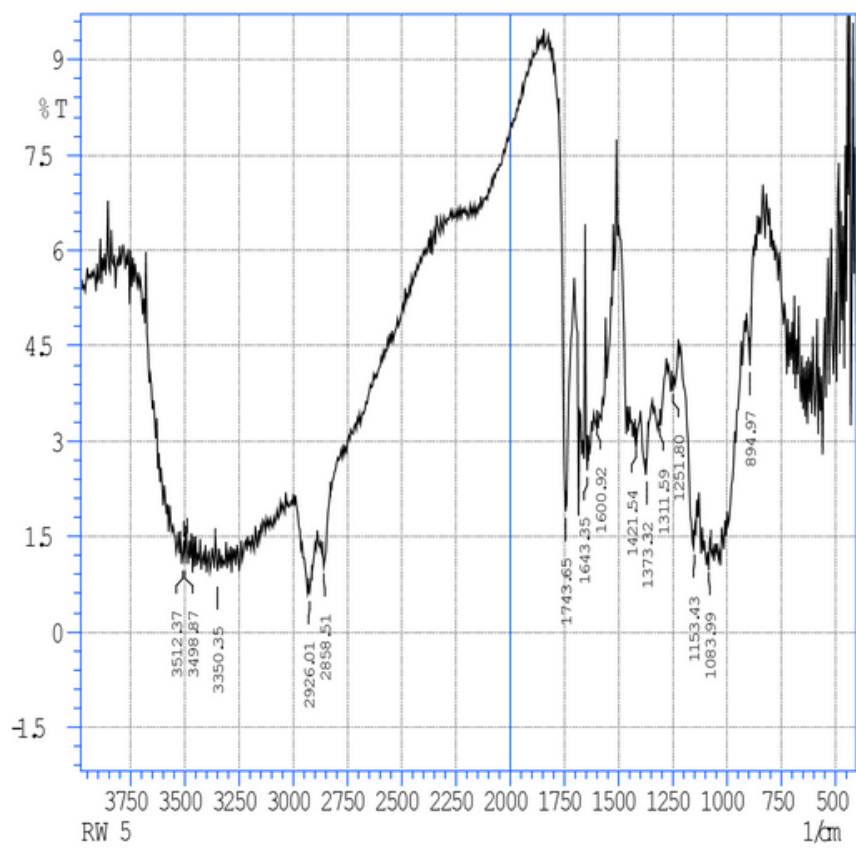

d. FTIR

\section{Figure 2}

FT-IR spectrum of chitosan film incorporated with ginger oil at different concentration.(a)control chitosan film,(b) ginger oil $0.1 \%$,(c) ginger oil $0.2 \%$,(d) ginger oil $0.3 \%$. 

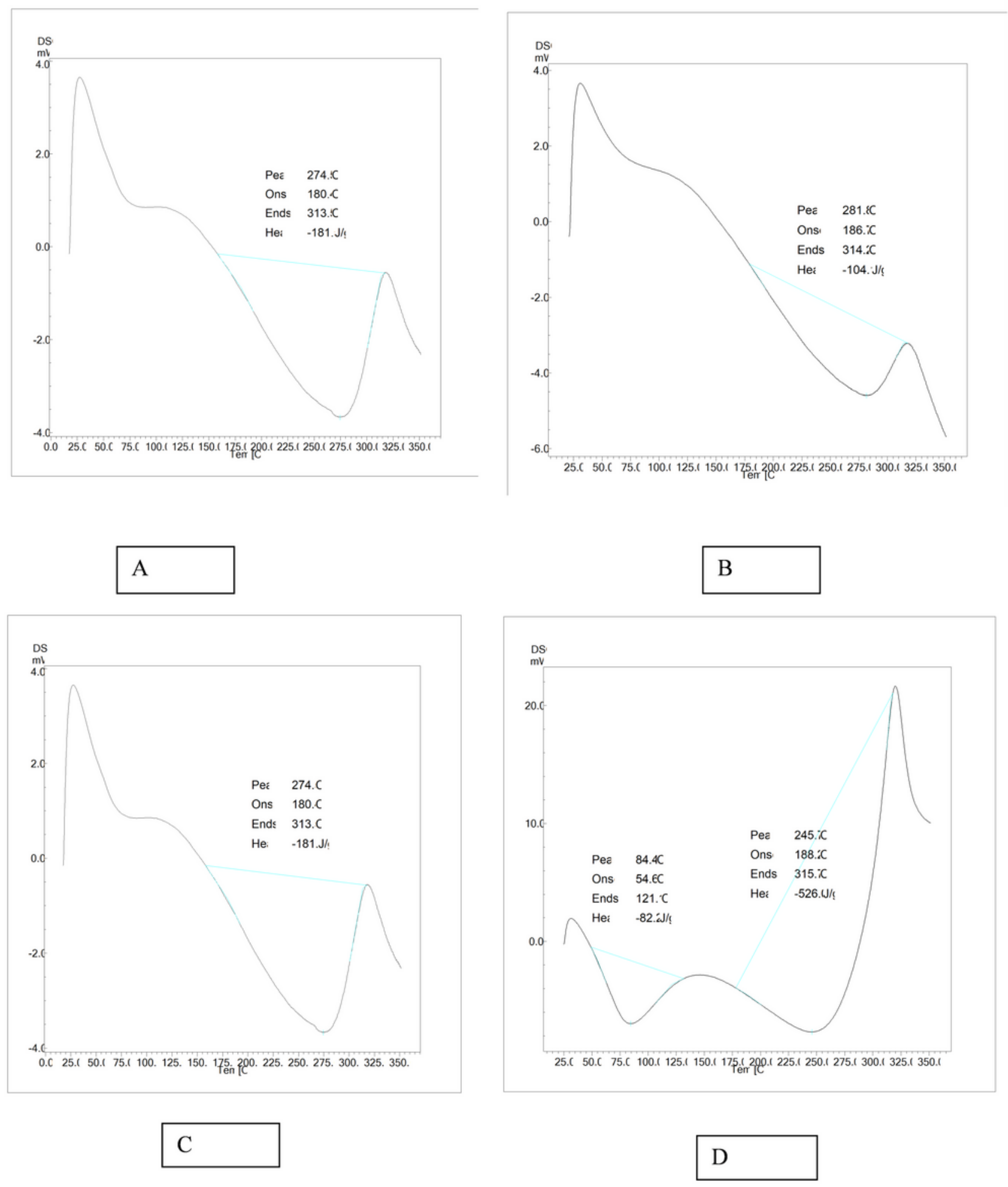

\section{Figure 3}

Differential scanning calorimeter of (a)control chitosan film,(b) ginger oil $0.1 \%$,(c) ginger oil $0.2 \%$,(d) ginger oil $0.3 \%$. 

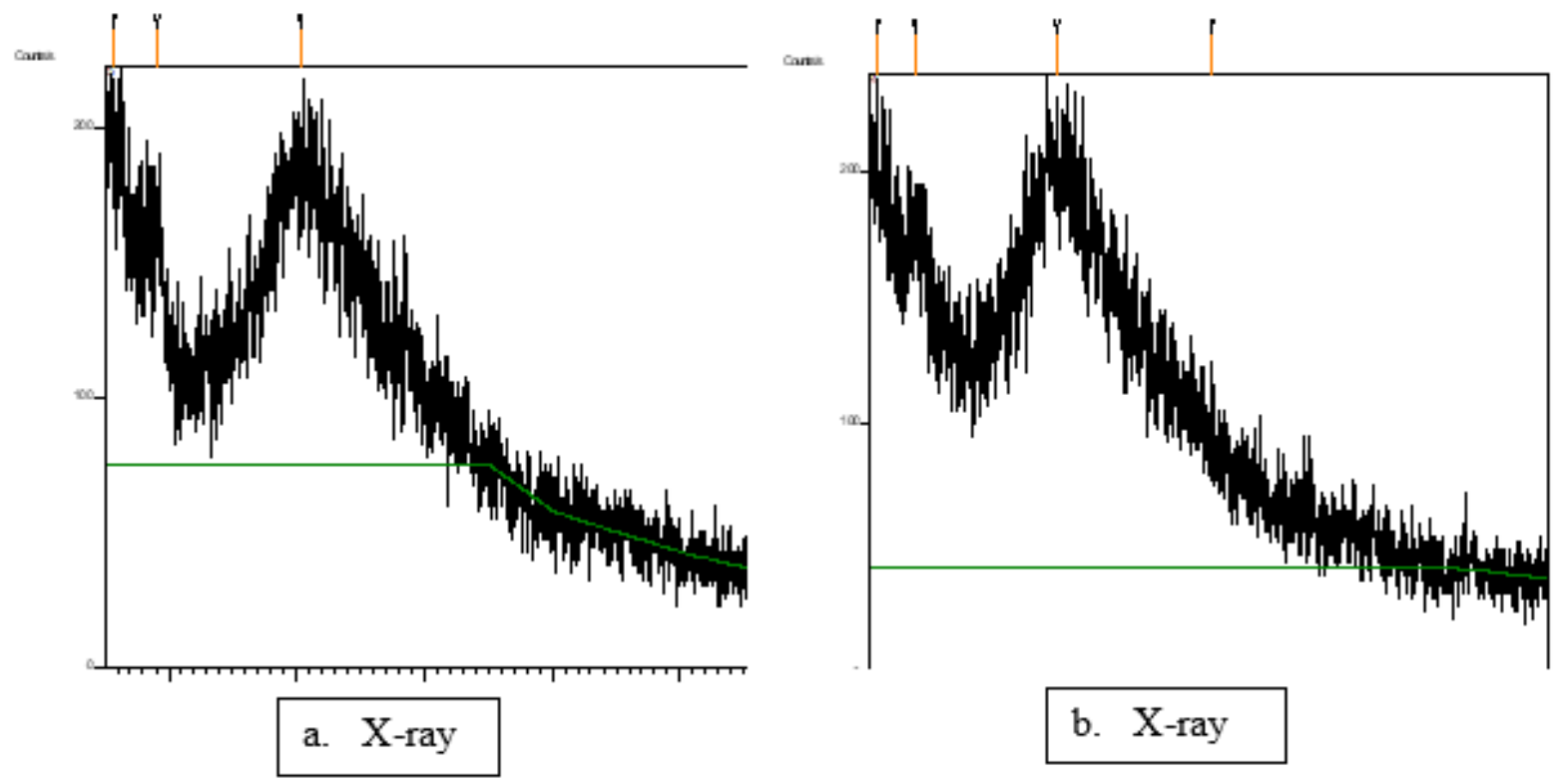

b. X-ray

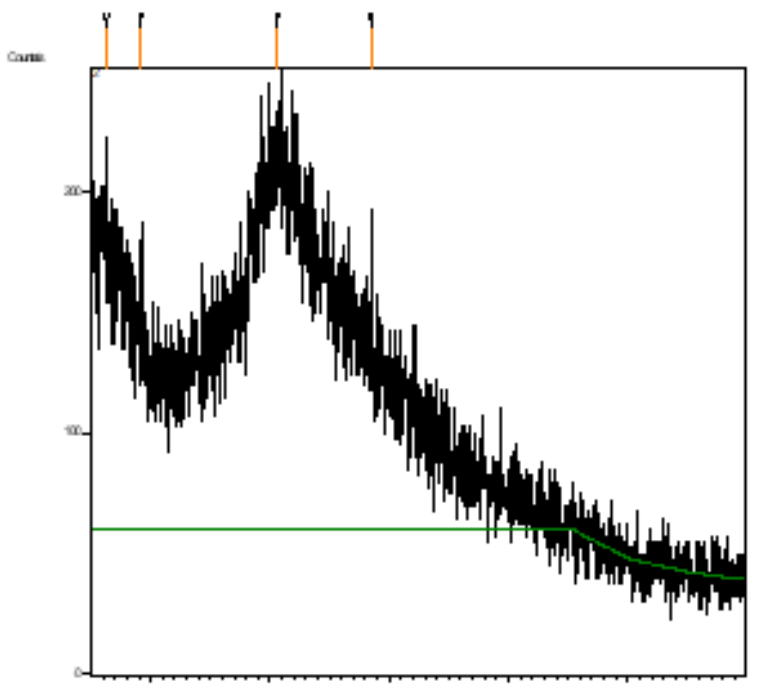

c. X-ray

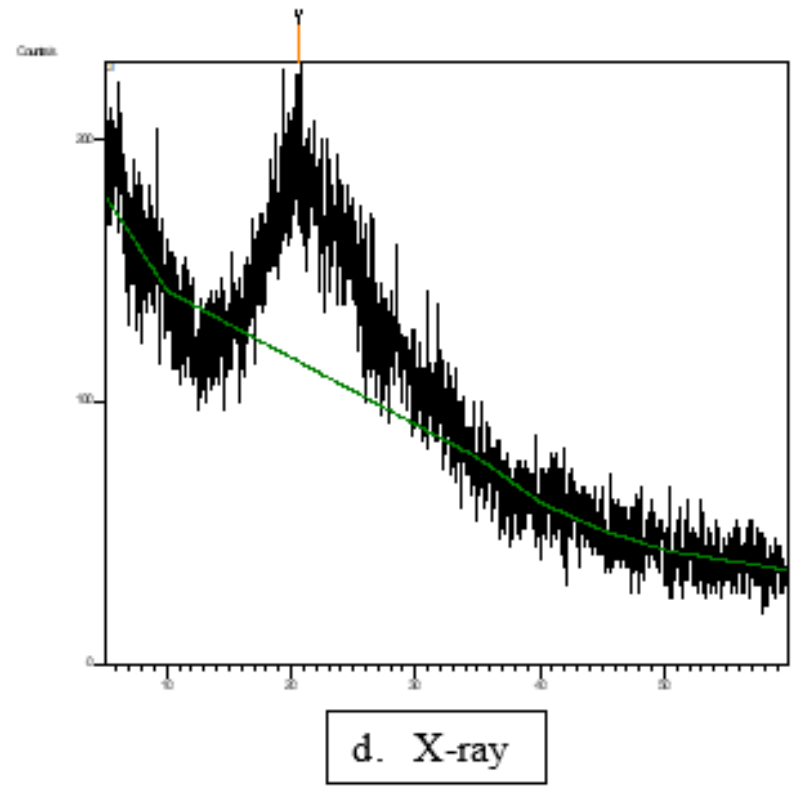

Figure 4

X-ray Diffraction patterns of (a)control chitosan film, (b) ginger oil $0.1 \%$, (c) ginger oil $0.2 \%$, (d) ginger oil $0.3 \%$. 